\title{
Work-Role Attachment and Retirement Intentions of Public School Teachers in Calabar, Nigeria
}

\author{
J. S. Petters and P.N. Asuquo* \\ Educational Foundations, Guidance and Counseling Department, Faculty of Education, \\ University of Calabar, Calabar, Nigeria \\ *E-mail: patasu001@yahoo.com
}

KEYWORDS Favourable. Committed. Plans. Teachers. Public School

\begin{abstract}
This study investigated the work role attachment and retirement intentions of public school teachers in Calabar, Nigeria. It was motivated by the observation that most public school workers lack plans for retirement and as such do not prepare for it until it suddenly dawns on them. Few empirical studies were reviewed. Questionnaire was the main instrument used for data collection from a sample of 200 teachers. Independent t-test was used to test the stated hypotheses at 0.05 level of significance. Results showed that the committed/attached/involved workers have retirement intention to take a part-time job after retirement. The uncommitted/unattached/uninvolved workers have intention to retire earlier than those attached to their work. It was recommended that pre-retirement counselling should be adopted to assist teachers to develop good retirement plans.
\end{abstract}

\section{INTRODUCTION}

Retirement is gradually becoming topic of research focus in today's contemporary Nigerian society. It is an important phase of life or life event, bringing with it many challenges in terms of adjustments and changes in lifestyle, selfesteem, friendships and vocation. It is often described as leaving the job at a specified period of time after putting in some number of years ( 35 years) or after attaining a given age of 60-65 years in Nigeria's public sectors of the economy.

Work is a fundamental value of all societies. It elects one's social and physical environment. As such it represents physical and mental activities through which a person maintains contact and interaction with the environment, thus facilitating a productive expression of his innermost aspirations and drives. According to Geston (1995), life is meaningful if attached to work, aside is to enter into a state of devaluation. Work is very significant as it affects attitudes and behaviour and provides a basis for improving of living standards of the individual worker. For a worker, work provides a sure means of achieving independence, leadership, self direction and gives a sense of belonging and identify. It is a result of the significance of work in a person's life, that some workers become so attached, committed, involved in their work. Work keeps them busy and they derive maximum benefits from it by devoting long hours into working. It is assumed that anything that will remove a committed worker off the job without accomplishment of needs satisfied by work may be resisted the worker will possess negative feelings towards such a situation. Retirement, therefore, seem to be one of those conditions bringing about disengagement of workers from their jobs. As stated by Amadi (1991) it involves leaving one's regular routine or habitual career, position, business or active life.

Viewed as such it could become a threat to many workers who may not know what to do with their time and lives after retiring from active service. To those workers so attached to their work, it is often assumed that it may pose a great challenge to them (Blunt 1983). This is manifest in terms of stress relating to changes in routine, changes in personal habits, and changes in opportunities for social interaction and for workers who take work as a central life interest, they are said to suffer most when the time to retire comes. Given that attachment and commitment to work and close personal identification with ones job can be said to be traumatic in face of retirement or biting unemployment, it is only logical that people plan for it. This however can not be done without adequate data reflecting intensions, hence the need for this study. The study seeks to examine the influence of work-role attachment on career intentions of public school teachers in a Nigerian setting.

\section{Work Role Attachment}

This refers to the process whereby one has a 
strong feeling of affection for one's job. To the committed workers, work is central to their identity. To them, work is a central life interest and has moral value and it is intrinsically good. Cohn (1979) suggested that shifts in centrality of work occur when retirement becomes relatively imminent, he ask men of different ages about the degree of intrinsic satisfaction they get from work. He then related their answers to a measure of overall satisfaction with life. Just as many older and younger men reported intrinsic satisfaction with their work, only in the younger men was a high level of work satisfaction positively correlated to overall happiness. In other words, although satisfaction with one's job does not decline with age, the emotional importance of one's work may diminish in just this way.

According to Olagboye (1998) there have been historically two opposed attitudes or orientations to work which are:

a. Work is a Means to an End: These are the instrumental workers. To them work is unpleasant but has to be endured in order to earn a living and to reach a desired end. They lack work-role attachment to their job.

b. Work is an End in Itself and can be Very Satisfying: These are the involved or the attached workers. They gain self-fulfillment through working. They are deeply attached to their jobs.

Adams et al. (2002) divide work-role attachment into three variables which are job involvement, affective organiza-tional commitment and career identification. Result of their work indicated that organizational commitment was negatively related to retirement intention. Contrary to expectations, job involvement displayed a positive relationship and career identification had no relationship to retirement interest.

Harris (2005) conducted a survey and found that 59 percent of older workers (over 55 years) agreed or strongly agreed that "a good deal of their pride comes from their work and career in comparison to 37 percent of those who are 18-34 years. A desire to keep working is expressed even among some of the most highly paid executives. 5 percent of the executives stated that they plan to work after retirement with just 18 percent anticipating going on full time retirement. Older workers (45 years and above) see their jobs as intrinsically enjoyable.

According to Belsky (1984) people who are attached and committed to their work should also be most adverse to the idea of living without working. Those who dislike their jobs should be most favourable to the thought of being retired. However, a person's attitudes toward work and retirement are not related in themselves. Workers who say they like their jobs feel just as favourable toward the idea of being retired as those who do not. (Glamser, 1976).

According to Blunt (1983) it could be technically concluded from the few studies done in Africa that vast majority of African workers can best be described as having a primarily instrumental orientation to work. This according to him is true of unskilled workers and a number of white collar workers. In a study conducted by Hutton (1969) among a sample of 200 unemployed persons in Uganda, he found that $72 \%$ of them had instrumental orientation to work. In another study conducted to identify factors which influence productivity in Nigeria with particular reference to motivation, Kayode (1970) found that the most significant factor of a job to the average Nigerian worker is the pay. Another factor of importance among lower level Nigerian worker is security of employment.

Price (1975) examined the value which Ghanaian civil servants faced on the various job characteristics of their work. He discovered that Ghanaian civil servants like the lower level of Nigerian workers placed much value on the security their jobs offered them. Job involvement is a stable characteristics of the personality of the individual which is in effect resistant to change. For this people, they continue to work as hard as ever doing one thing or the other even after retirement.

Vecchio (1980) discovered that the percentage of American workers who displayed instrumental orientation to work had increased while those with involved orientation to work had decreased. American male workers who would stop working if given the choice had increased by $30 \%$. In other words about $60 \%$ of American male workers confirmed that they would abandon their jobs were they to inherit enough money to enable them live comfortably without working.

\section{Retirement Intentions}

This refers to what one plans or intends to do with regards to retirement. It may also refer to what one would like to do in order to have a satisfying and personally productive life replacement after retiring from work so that life 
continues to have meaning and reward. Some workers may intend to retire earlier; others may retire later, while some do not have any fix ideas about when to retire until when forced on them. There also those who intend to retire into some form of employment (private businesses, part-time job, politics or active involvement in religious matters). The attitude one has towards retirement influences how one feels after being retired. If the worker anticipates it with pleasure and good plans retirement will be worthwhile. Without good intentions and plans to keep busy, get extra source of income outside pension, retirement can be traumatic and unpleasant.

Guillemard (1982) identifies five types of retirement patterns or intentions. These are:

i. Withdrawal - extreme reduction of social activity

ii. Professional activities giving way to creative activities (artistic creation, hobbies) and cultural improvement.

iii. Leisure retirement - The focus is on leisure activities (holiday journeys, exhibitions, theatre shows etc) with an emphasis on consumption.

iv. Protest retirement characterized by political activism.

v. Acceptance retirement - acceptance of traditional retirement values.

Those who have professional background tend to be clustered in groups two and three while those with working- class background are overrepresented in other groups (i, iv,v).

Snow and Havighurst (1977) identified two contrasting retirement patterns or intentions related to successful adjustments. These are:

a. Transformers

b. Maintainers

The transformers reduce their professional activity and create a new life-style after retirement. They choose a non-professional activity such as hobbies, travel, community affairs or politics. They do not relax and do nothing. The maintainers on the other hand hold on to professional activity. They work part-time after formal retirement and supplement their work with leisure activities in order to occupy their time.

Favourable and positive attitudes toward retirement are associated with planning, having intentions to occupy one's time, counselling, personal discussion about retirement and exposure to news media about retirement. Workers need to be socialized into post-work roles just as they are socialized into other roles. Workers need to anticipate and plan for retirement. This can be done by saving money because small amounts add up over the years, decide what one wants to do for oneself, begin early to care for one's health, form relationships now that have depth and meaning with a sense of performance and expanding one's interest now so that one's work is not the primary focus and source of income.

Some workers when faced with the reality of retirement seek solace in compensation or rationalization. They compensate for their lack of status in an occupation by participating in a devoted manner in clubs and organizations which eventually give them roles of leadership. Some participate actively in religious activities while some may turn to recreation to alleviate disappointment in their jobs.

Schlossberg (2004) in a study of 100 retirees, found that retirement is not one but many transitions that coping with these transitions depend on the following:-

- The role of work and family in the life of the individual

- The timing of retirement

- The degree to which retirement is planned for

- The degree to which work has been satisfying

- The expectations one has about retirement

- The degree to which a meaningful life is established.

- One's health and sense of financial security. She identified the following retirement intentions of people

a. Continuers - who continue using existing skills and interests

b. Adventurers - who start entirely new endeavours

c. Searchers - who explore new options through trial and error.

d. Easy gliders - who enjoy unscheduled time letting each day unfold.

e. Involved spectators - who care deeply about the world, but engage in less active ways.

f. Retreaters - who take time out or disengage from life.

Qualls and Abeles (2002) found that those people most happy in retirement enjoy a variety of activities, ranging from volunteer work, exercise, and continuing education. Many on the road to retirement plan to spend a lot of time traveling but at times unexpected physical ailments may make extensive traveling difficult. In a study conducted by Ubangha and Akinyemi 
(2005) on the relationship between attitude to retirement planning and retirement anxiety among teachers in four local government areas of Lagos metropolis, result showed $65 \%$ of the teacher indicated willingness to continue teaching after retirement if given the chance.

Many workers do not really know what they want for a lifestyle in retirement. Knowing what they do not want may be the first step but does not answer the question, what will my life look like in retirement? There is need to assist workers get a clearer vision of their retirement intentions and destinations.

\section{Statement of the Problem}

As the public service is expanding, many workers are equally leaving the service voluntarily, compulsory or mandatorily. Retirement is a threat to many workers who may not know what to do with their lives after retiring from active service (Nsirimobi and Nguwede, 2005). Many workers in developing countries treat lightly the absolute need to prepare for retirement from service. Some of the workers in public service are very attached to their work and they work devotedly and committedly to raise the profile of their institutions or organizations without considering the fact that one day they will be asked to vacate their posts or jobs. To this group, work fascinates them and they derive satisfaction from their jobs without making good plan as to when to retire and what to do after retirement. They fail to realize that retirement can bring stress even when it is voluntary through changes in personal habits, changes in routine and changes in opportunities for social interaction.

Some workers after meeting their regular monthly bills, do not save money and thereby deter themselves from adequately preparing for inevitable retirement. No savings and no personal businesses and at retirement, they realize they have prepared nothing to augment their pensions which may be insufficient to cater for all their needs and sustain them comfortably at old age: Another problem of retirement benefit is that the pension is not usually up-dated periodically by the employer to prevent consequent reduction in value as a result of inflation. This further leads to more frustration of the retirees especially when another source of sustenance is absent.

There is need for workers to take time and plan for what they will engage their time in after retirement. Lack of this leads to frustration, boredom and depression. Workers whether attached to their work or not attached, committed or not committed, involved or not involved in their work need to view retirement positively so that life continues to have meaning and reward in retirement years.

\section{Purpose of Study}

This study seeks to find out the retirement intentions of public teaching servants in Calabar, Nigeria. It is to establish whether workers attached or not attached to their work have different retirement intentions.

One will also find out if those attached to their work intend to retire earlier than those who are not attached.

\section{RESEARCH QUESTIONS}

This study is designed to examine the following questions

1. Do workers attached to their work (involved workers) differ in retirement intentions to keep working on part-time basis after retirement from those who are not attached to the work (uninvolved workers).

2. Do they also differ in terms of when to retire?

\section{Hypotheses}

1. The involved workers are not significantly different from the uninvolved workers in their retirement intentions to take a part-time job.

2. The uninvolved/unattached workers are not significantly different from the involved/ attached workers in their intention to retire early.

\section{METHDOLOGY}

The research is a survey design. The population consisted of all the primary and secondary school teachers in Calabar, Nigeria. The sample selected for the study comprised of 200 teachers, 100 teachers from primary schools and 100 teachers from secondary schools. The subjects were drawn from public schools in Calabar. The schools used, were randomly selected from the overall number of schools in the area of study.

A research designed questionnaire was utilized to generate the relevant data. It consisted 
of two sections - A and B, Selection A sought the personal and employment data of the respondents such as age, sex, marital status, grade level, years of service.

The second section consisted of 30 items designed by the researcher to assess work role attachment and retirement intentions of the public school teachers. Twenty items assessed work role attachment of teachers while ten items assessed their retirement intentions. All the 30 items in section B were on a four-point rating scale of strongly agree, agree, disagree and strongly disagree. Positive items were directly scored while negative items were reversely scored.

\section{RESULTS}

The data collected was analyzed using the independent t-test. The null hypotheses were tested at 0.05 level of significance.

\section{Hypothesis One}

The involved workers are not significantly different from the uninvolved workers in the retirement intentions to take a part-time job. The independent variable is type of workers while the dependent variable is retirement intention of taking a part-time job. Independent t-test is used to compare the mean ( $\mathrm{x}$ ) of the involved and the uninvolved workers in their retiring into a parttime job. A summary of the result is presented in Table 1

Table 1: Independent t-test analysis of the difference between involved and uninvolved workers in retiring into pat-time job

\begin{tabular}{lcccc}
\hline Variables & $N$ & $X$ & $S D$ & t-value \\
\hline Involve workers & 122 & 88.10 & 10.22 & $9.18^{*}$ \\
Uninvolved workers & 118 & 75.16 & 11.53 & \\
\hline
\end{tabular}

*significant at $0.05, \mathrm{df}=238$; critical $\mathrm{t}-1.968$.

Results in this table indicated that the calculated t-value is 9.18 while the critical value is 1.968 at 0.05 level of significance with 238 degrees of freedom. It is observed than the calculated tvalue is greater than the critical t-value and as such the null hypothesis is rejected. Further breakdown of the result showed that the involved or committed workers $(x=88.10)$ have intentions to take a part-time jobs after retirement unlike the uninvolved workers (x-75.16). Given this result therefore, involved workers are significantly different from uninvolved workers in their retirement intentions to take a part-time job after retirement.

\section{Hypothesis Two}

The uninvolved/unattached workers are not significantly different from the involved/attached workers in their intentions to retire early.

Early retirement refers to those teachers who have the intention to retire before 60 years of age or before 35 years of public service. The independent variable is type of workers while the dependent variable is early retirement. Independent t-test is used to compare the mean intentions of the uninvolved and involved teachers. A summary of the result is presented in Table 2

Table 2: Independence t-test statistical analysis of the difference between uninvolved and the involved teachers in their early retirement intentions

\begin{tabular}{lcccc}
\hline Variables & $N$ & $X$ & $S D$ & t-value \\
\hline Uninvolved teachers & 109 & 92.41 & 14.24 & $8.27 *$
\end{tabular}

$\begin{array}{llll}\text { Involved teachers } & 131 & 79.34 & 9.07\end{array}$

*significant at $0.05, \mathrm{df}=238$; critical $\mathrm{t}-1.968$.

Result in table 2 revealed that the calculated $\mathrm{t}$-value is 8.27 while the critical value is 1.968 at 0.05 level of significance with 238 degrees of freedom. It is observed that the calculated t-value is higher than the critical t-value, the null hypothesis is hereby rejected. With this result therefore, there is a significant difference in early retirement intentions of uninvolved and involved workers. A further look at the result indicated that teachers who are not attached or committed to their work has a higher mean intentions ( $x=92.41)$ than those who are attached to their work $(\mathrm{x}=79.34)$. this means those teachers who are not attached to their work have intentions to retire early from service. While those who are attached to their work want to continue working or retire late.

\section{DISCUSSION}

\section{Hypothesis One}

This hypothesis sought to find out if there is a significant difference in retiring into a part time job of the involved teachers and the uninvolved. 
The result of this study has revealed that there is a significant difference in the retirement intentions of taking a part time job of the involved and the uninvolved teachers (see table 1). The null hypothesis is rejected contrary to the wide speculations that workers who are deeply committed to their official work maybe too involved to plan for their retirement. This finding disagrees with Blunt (1983) that those workers who take work as a central life interest suffer most when the time to retire comes. According to him, given their commitments to work and their close personal identification with their jobs, retirement can be traumatic. From this finding however, it is obvious that those workers attached to their work intend to take to a part-time job after retirement.

In agreement with this study is the work of Snow and Havighurst (1977) that referred to committed workers as the "maintainers" while Schlossberg (2004) refers to them as the "continuers". They hold on to or maintain their professional activity. Some prefer to work parttime after formal retirement and supplement their work with leisure activities. The rejection of this null hypothesis must not be unconnected with the fact that those who are committed or attached to their public service work may not want to be idle at retirement. They are serious minded and hardworking who want to leave service at retirement but keep working by taking a part-time job. They are very focus in nature and so intend to continue rendering services after retirement. Also in agreement with this finding is the work carried out by Ubangha and Akinyemi (2005), the result of their findings confirm that about $65 \%$ of the teachers indicated willingness to continue teaching after retirement if given the chance. The involved and committed teachers indicate their intentions to take to a part-time teaching job if given the opportunity.

\section{Hypothesis Two}

The involved/unattached workers are not significantly different from the involved/attached workers in their intention to retire early. This null hypothesis was rejected. This means those teachers not attached to their job intend to retire earlier than those who are attached. This is in agreement with Belsky (1984) that people who are attached and committed to their work should also be most adverse to the idea of living without working. On the other hand, those who dislike and not committed to their jobs should be most favourable to the thought of being retired. However, in disagreement is the work of Glamser (1976) that a person's attitudes toward work and retirement are not related in themselves. Workers who say they like their jobs feel just as favourable toward the idea of being retired early as those who do not.

Olagboye (1998) refers to those not attached to their work as the instrumental workers. They work to earn a living. To them work is unpleasant. According to Vecchio (1980), the instrumental workers who work only for the sake of their salaries indicated that they would abandon or retire from their jobs were they to inherit enough money to enable them live comfortably without work. These are the uninvolved workers. In agreement also with this finding is the work of Pollman (1971), that as lack of involvement in one's job and dissatisfaction with jobs increase, the desire to leave the work situation increase leading to early retirement.

\section{CONCLUSION}

This work has examined work role attachment and retirement intentions of public school teachers in Calabar, Nigeria. Findings suggest that workers or teachers who are committed/attached/ involved in their work have retirement intentions to take to a part-time job after retirement from service. Those teachers not attached to their jobs have no such intentions. It also reveals that those teachers who are not attached, committed or involved in their jobs have the intentions to retire early from their jobs. Those attached to their jobs will love to keep working until the mandatory retirement comes at a specified age or years of service. Given the above results, it becomes necessary to recommend pre-retirement counselling early in career life span of teachers in which the psychological aspects of retirement and financial aspects are discussed.

\section{REFERENCES}

Adams GA, Presher J, Beehr TA, Lepisto L. 2002 Applying work-role attachment theory to retirement decision making. Int J Aging Hum Dev, 54(2): $125-137$.

Amadi AO 1991. Preparing for and Managing Your Retirement. Owerri: Dolf Mdi International Ltd.

Belsky IK 1984. The Psychology of Aging Theory, Research and Practice. California: Brooks/Cole Publishing Co. 
Blunt P 1983. Organizational Theory and Behaviour. London: Longman.

Cohn RM 1979. Age and the satisfaction from work. Journal of Gerontology, 34: 264-272.

Geston GH 1995. Reactions to retirement. In: A. Omeresemi. (Ed.), Challenges in Retirement and How to Have a Happy and Successful Old Age. Kano: Baptist Church Press, Pp. 45-55.

Glamser FO 1976. The impact of pre-retirement programs on the retirement experience. Journal of Gerontology, 36: 244-250.

Guillemard A 1982. Old age retirement and social class structure. In: T. Haraven and K. Adams (eds.), Aging and Life Course Transitions. New York: Guilford Press, Pp. 234-245.

Harris I 2005. Many U.S. employees have negative attitudes to their jobs, employers and top managers. Available on line at http.//yahoo.com/pmars/050 505/ny 1068.html.

Hutton C 1969. Unemployment in Kampala and Jinja, Uganda. Canadian Journal of African Studies, 3: 431-440.

Kayode MO 1970. A re-examination of the concept and factors influencing productivity with particular emphasis on motivation. Nigerian Journal of Economic and Social Studies, 12: 45-60.

Nenty NI 2004. Personality Traits and Post Retirement Adjustment of Public Servant in Akwa Ibom State of Nigeria. Unpublished Ph.D Dissertation. Calabar: University of Calabar.
Nsirimobi OS, Aguwede IM 2005. Effectiveness of Group Counselling and Bibilotherapy on Workers Retirement Adjustment in Port-Harcourt Local government area of Rivers State. The Counsellor, 21: 137145.

Olagboye AA 1998. Joys and Agonies of Retirement and Job Loss. Lagos: Joja Press Ltd.

Pollman AW 1971. Early retirement relationship to variation in life satisfaction. The Gerontologist, 1: 43-47.

Price RM 1975. Society and Bureaucracy in Contemporary Ghana. Berkeley: University of Califonia Press.

Qualls S, Abeles N (Eds.). 2002. Psychology and the Aging Revolution. How We Adapt to Longer Life. Washington DC: American Psychological Association.

Schlossberg N 2004. Retire Smart, Retire Happy: Finding Your True Path in Life. Washington D.C.: American Psychological Association.

Snow RB, Havighurst 1977. Lifestyle Types and Patterns of Retirement of Education. Gerontologist, 17: 545 -552 .

Ubangha MB, Akinyemi, BA 2005. The Relationship between attitude to retirement planning and retirement anxiety among teachers. The Counsellor, 21: $156-163$

Vecchio RP 1980. The function and meaning of work and the Job: Morse and Weiss 1955 revisited. Academy of Management Journal, 23: 361-367. 